\title{
POST-TRAUMATIC HEADACHE
}

\author{
Hugo André de Lima Martins', Valdenilson Ribeiro Ribas², Bianca Bastos Mazullo Martins', \\ Renata de Melo Guerra Ribas ${ }^{4}$, Marcelo Moraes Valença ${ }^{5}$
}

\begin{abstract}
The onset of post-traumatic headache (PTC) occurs in the first seven days after trauma, according to the International Headache Society (IHS) classification. The objective of this study was to evaluate the several forms of headache that appear after mild head injury $(\mathrm{HI})$ and time interval between the $\mathrm{HI}$ and the onset of pain. We evaluated 41 patients with diagnosis of mild $\mathrm{HI}$ following the IHS criteria. Migraine without aura and the chronic tension-type headache were the most prevalent groups, occurring in $16(39 \%)$ and $14(34.1 \%)$ patients respectively. The time interval between $\mathrm{HI}$ and the onset of headache was less than seven days in 20 patients (48.7\%) and longer than 30 days in 10 (24.3\%) patients. The results suggest that PTC may arise after a period longer than is accepted at the present by the IHS.
\end{abstract}

KEY WORDS: headache, post-traumatic headache.

\begin{abstract}
Cefaléia após traumatismo cranioencefálico
Resumo - O início da cefaléia pós-traumática (CPT) ocorre dentro de sete dias após o trauma, de acordo com a classificação da Sociedade Internacional de Cefaléia (SIC). O objetivo deste estudo foi avaliar as diversas formas de cefaléia que surgem após o traumatismo cranioencefálico (TCE) leve e o intervalo de tempo entre o TCE e o início da dor. Foram avaliados 41 pacientes com diagnóstico de cefaléia pós-traumática leve segundo os critérios da SIC. Migrânea sem aura e cefaléia do tipo tensional crônica foram os tipos de cefaléia mais comuns, ocorrendo em 16 (39\%) e 14 (34,1\%) dos pacientes respectivamente. O intervalo de tempo entre o TCE e o início da cefaléia foi menor que sete dias em 20 pacientes (48\%) e maior que 30 dias em 10 (24,3\%) pacientes. Estes resultados sugerem que a CPT pode surgir após período maior do que é aceito atualmente pela SIC.
\end{abstract}

PALAVRAS-CHAVE: cefaléia, traumatismo cranioencefálico.

Post-traumatic headache (PTH) is usually one of several symptoms of the post-traumatic syndrome ${ }^{1-3}$. Therefore, may be accompanied by somatic, psychological or cognitive disturbances ${ }^{4-6}$. The etiology of these symptoms in individuals with mild traumatic brain injury or whiplash injury has been a subject of some controversy with explanations ranging from neural damage to malingering ${ }^{7}$. The PTH can resemble a tension-type headache, migrainous or cervicogenic headaches ${ }^{7}$. The pathogenesis of PTH is still not well-known but might share some common headache pathways with primary headaches ${ }^{2}$. The problem, conversely, arises in PTH after a light trauma, since it is difficult to establish the cause-effect link ${ }^{8}$. There seems to be an inverse relation between the severity of the head trauma and the occurrence of a PTH, especially the chronic type ${ }^{9}$. Psychological factors are believed to play a role in the cause, maintenance and relief of chronic PTH.

The evaluation of the person with post-traumatic headache remains a difficult clinical task ${ }^{10}$. Although most cases of PTH are resolved within 6 to 12 months, many patients have protracted or even permanent head$a^{\text {ache }}{ }^{11}$. Because PTH usually has no objective findings, it is often controversial whether the symptom is "real," "psychogenic," or "fabricated"11. Although the IHS criteria stipulate that PTH should have an onset within one week of the trauma, it has been observed that a headache linked to the trauma can start later?.

The objective of this study is to characterize the headaches that arise after mild head injury (HI), and to evaluate the time interval between the $\mathrm{HI}$ and the headache onset.

Pós Graduação em Neuropsiquiatria e Ciências do Comportamento, Universidade Federal de Pernambuco, Recife PE, Brazil (UFPE): 'Mestre em Neurologia; ${ }^{2}$ Mestre em Neurociências; ${ }^{3}$ Graduada em Psicologia, Universidade Católica de Pernambuco; ${ }^{4}$ Graduanda em Nutrição, Pós Graduanda em Gestão de Qualidade e Vigilância Sanitária em Alimentos; ${ }^{5}$ Doutor em Fisiologia Geral da Universidade de São Paulo, Professor Associado de Neurologia e Neurocirurgia da UFPE.

Received 10 June 2008, received in final form 3 October 2008. Accepted 14 November 2008.

Dr. Valdenilson Ribeiro Ribas - Avenida Armindo Moura 581 / Quadra D / Bloco 02 / Ap 201 / Conjunto WXL - $51130-180$ Recife PE - Brasil. E-mail: ribaspsy@ufpe.br 


\section{METHOD}

This was a prospective study of patients seen in the Headache Clinic of Pernambuco Federal University from 2004 to 2006. Ninety-five patients after mild HI were assessed. Fifty-four of these patients were excluded due to the presence of headache prior to the $\mathrm{HI}$, inadequate information related to the onset of headache or absence of headache complaint after $\mathrm{HI}$. Of the remaining 41 patients, 22 men and 19 women all met the criteria to the mild $\mathrm{HI}$ according to the International Headache Society (IHS) guidelines: $\mathrm{HI}$ with loss of consciousness less than 30 minutes or its absence, and the Glasgow scale superior to 13.

All patients presented the neurological exam normal and no complementary exam was realized.

It was performed an initial assessment of all patients, in which it was questioned the main features of headache like: location of pain, duration, precipitant factors, installation way and associated symptoms, being included in the group of migraine, tension-type headache or cluster headache.

After the first interview, each patient included in this study was assessed once for each thirty days, during six months, to appreciate the headache's evolution. It was also researched the time interval between the $\mathrm{HI}$ and the headache onset, being all patients divided into four groups according to the following criterion: headache beginning up to 7 days, 7 to 14 days, 14 to 28 days, and over 30 days after the HI. The study was aproved by the Local Ethics Committee and all patients signed an informed consent.

\section{RESULTS}

Forty-one patients with mild $\mathrm{HI}$ who had attended the neurology clinic from 2004 to 2006 were assessed. Fig- ure 1 demonstrates the distribution of data for each type of headache after the HI. The migraine without aura and the chronic tension-type headache were the most prevalent groups, occurring in $16(39 \%)$ and 14 (34.1\%) patients respectively, whereas the episodic cluster headache occurred in only one patient (2.4\%).

The interval of time between the $\mathrm{HI}$ and the onset of headache is shown in Figure 2.

The onset of PTH occurred in the first seven days after the $\mathrm{HI}$ in 20 (48.7\%) patients, whereas 10 (24.3\%) patients presented the onset of headache beyond thirty days of $\mathrm{HI}$.

\section{DISCUSSION}

Post-traumatic headache is a general term for pain localized in the head or neck, occurring after head trauma and varied etiology and pathogenesis ${ }^{12,15}$. In many cases one only finds a time-dependent relation to trauma, but no causal one. There is no uniform, typical "post-traumatic headache". The headaches are commonly caused by injury to scalp, cervical spine and intracranial structures ${ }^{15-18}$. It is usually difficult to decide whether the post-traumatic headache is exclusively caused by organic or psychogenic factors. Probably both factors are involved to an individually different degree $e^{12,19,20}$.

In the some authors view, genuine chronic PTH exists only in very rare cases and is always associated with considerable organic intracranial lesions ${ }^{13}$.

There has been relatively little information dealing with the characteristics of the headache in the post-trauma syndrome ${ }^{14}$. The data suggested that the majority of

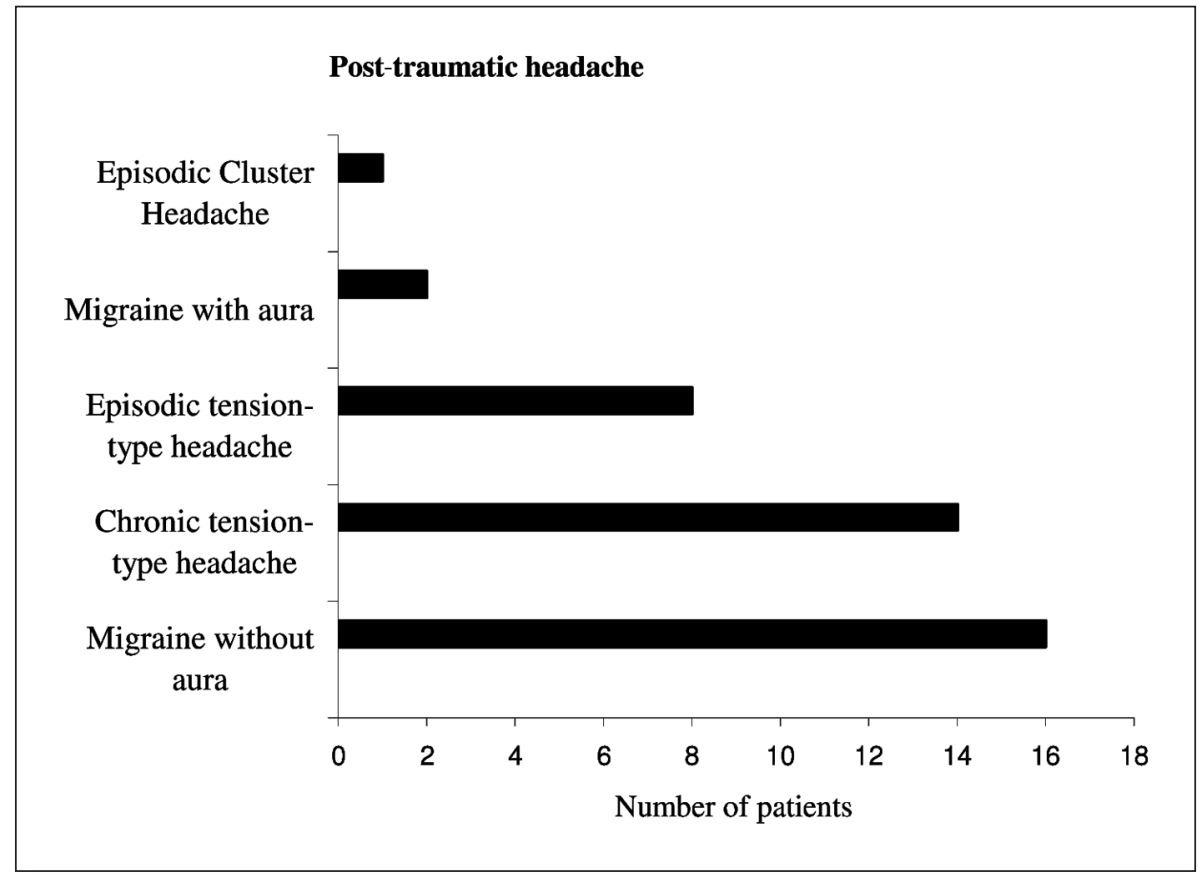

Fig 1. Characteristics of post-traumatic headache. 


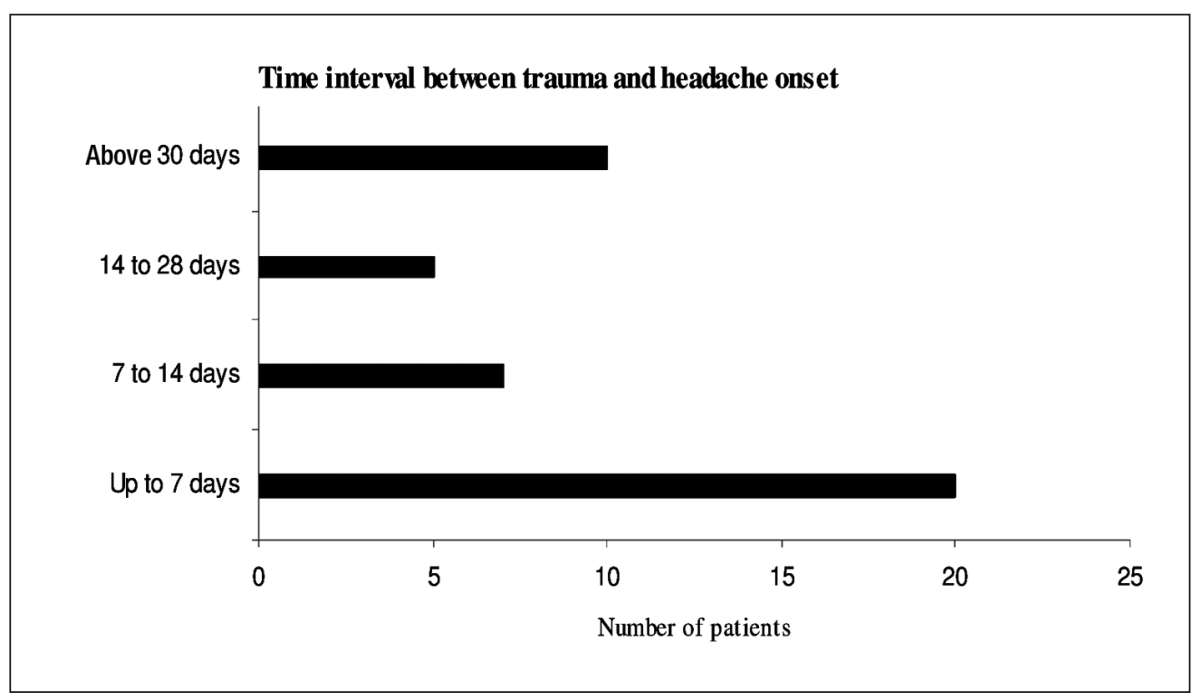

Fig 2. Time interval between trauma and headache onset.

patients in the present study had headaches that could be classified by the IHS criteria as episodic or chronic tension-type headache or intermittent migraine.

In this paper, the most common PTH, were migraine without aura and chronic tension-type headache. In a study that assessed 27 patients relating mild $\mathrm{HI}$ and chronic headache, these types of headaches were more prevalent too ${ }^{15}$.

By definition, the headache that develops within one week after head trauma (or within one week after regaining consciousness) is referred to as $\mathrm{PTH}^{16}$. In the first edition of the IHS classification, the time interval between trauma and headache beginning was 14 days, reducing to one week in the last edition. In this paper, a quarter of the patients had symptoms only after thirty days of $\mathrm{HI}$.

Although sensitive fibers imprisonment in lesion point and anomalous regeneration is common in local headache, it may be a part of the explanation for the later beginning of other types of headache like migraine and tension type headache.

Some authors believe that PTH is a brain dysfunction manifestation aggravated by muscle skeletal injury. Acute headache may be provoked by lesion of the scalp tissue. Stimulus in muscle skeletal tissue may provoke neuroplastic alteration in the neuron of caudalis trigeminal nucleus, promoting wind up and sensibilization phenomenon. With continuous stimulus, there is an increased sensitiveness of dorsal corner neuron, provoking an increase of spontaneous activity, reduced threshold of pain and altered processing of afferent stimulus which can explain in part the source and maintenance of $\mathrm{PTH}^{12,17}$.

Trauma event and headache start, must be correlate in time, but as the exact mechanism of start and maintenance of PTH is not known, this time interval must be continuous- ly discussed with the aim of framing the largest number of patients in these criteria, allowing a reasonable treatment.

\section{REFERENCES}

1. O'Bryant SE, Marcus DA, Rains JC, Penzien DB. The neuropsychology of recurrent headache. Headache 2006; 46:1364-1376.

2. Pascual-Lozano AM, Salvador-Aliaga A, Lainez-Andres JM. [Posttraumatic headache. Pathophysiology, clinical, diagnostic and therapeutic aspects]. Neurologia 2005; 20:133-142.

3. Martelli MF, Grayson RL, Zasler ND. Posttraumatic headache: neuropsychological and psychological effects and treatment implications. J Head Trauma Rehabil 1999; 14:49-69.

4. Goldstein J. Posttraumatic headache and the postconcussion syndrome Med Clin N Am 1991; 75:641-651.

5. Packard RC, Weaver R, Ham LP. Cognitive symptoms in patients with posttraumatic headache. Headache 1993; 33:365-368.

6. Lyczak P, Lyczak-Rucińska M. Chronic post-traumatic headache and brain perfusion changes assessed using magnetic resonance imaging. Neurol Neurochir Pol 2005; 39:49-54.

7. Gurr B, Coetzer BR. The effectiveness of cognitive-behavioural therapy for post-traumatic headaches. Brain Inj 2005; 19:481-491.

8. Moscato D, Peracchi MI, Mazzotta G, Savi L, Battistella PA.Post-traumatic headache from moderate head injury. J Headache Pain 2005 6:284-286.

9. Lenaerts ME, Couch JR. Posttraumatic headache. Curr Treat Options Neurol 2004;6:507-517.

10. Zafonte RD, Horn LJ. Clinical assessment of posttraumatic headaches J Head Trauma Rehabil 1999;14:22-23.

11. Packard RC. Posttraumatic headache. Semin Neurol 1994;14:40-45.

12. Wessely PHF. On the problem of post-traumatic headache. Wien Klin Wochenschr 1987; 99:549-554.

13. Scherzer EB. [On the so-called posttraumatic headache (author's transl)]. Fortschr Neurol Psychiatr Grenzgeb 1975; 43:271-283.

14. Couch J. Chronic Daily headache in the posttrauma syndrome: relation to extent of head injury. Headache 2001; 41:559-564.

15. Souza JA, Moreira PF, Jevoux CC. Cefaléia pós-traumática crônica em traumatismos crânio-encefálicos leves. Arq Neuropsiquiatr 1999;57:243-248.

16. Lew PH, Fuh JL, Wang SJ, Clark DJ, Walker WC. Characteristics and treatment of headache after traumatic brain injury: a focused review. Am J Phys Med Rehabil 2006; 85:619-627.

17. Speciali JG, Farias da Silva W. Cefaléias. São Paulo: Lemos Ed; 2002.

18. Marcus DA. Disability and chronic posttraumatic headache. Headache 2003; 43:117-121.

19. Tatrow K, Blanchard EB, Hickling EJ, Silverman DJ. Posttraumatic headache: biopsychosocial comparisons with multiple control groups. Headache 2003; 43:755-766

20. Solomon SMD. Chronic post-traumatic neck and head pain. Headache 2005;45:53-67. 